The University of Southern Mississippi

The Aquila Digital Community

Faculty Publications

5-1-2009

\title{
Women, Work, and Family in the Antebellum Mountain South
}

Max L. Grivno

University of Southern Mississippi, Max.Grivno@usm.edu

Follow this and additional works at: https://aquila.usm.edu/fac_pubs

Part of the History Commons

\section{Recommended Citation}

Grivno, M. L. (2009). Women, Work, and Family in the Antebellum Mountain South. Journal of Interdisciplinary History, 40(1), 115-117.

Available at: https://aquila.usm.edu/fac_pubs/1242

This Book Review is brought to you for free and open access by The Aquila Digital Community. It has been accepted for inclusion in Faculty Publications by an authorized administrator of The Aquila Digital Community. For more information, please contact Joshua.Cromwell@usm.edu. 


\section{PROJECT MUSE}

Women, Work, and Family in the Antebellum Mountain South (review)

Max Grivno

Journal of Interdisciplinary History, Volume 40, Number 1, Summer 2009, pp. 115-117 (Review)

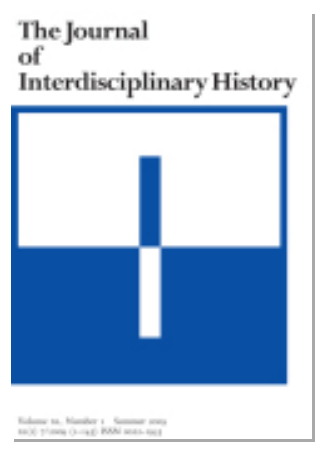

Published by The MIT Press

$\Rightarrow$ For additional information about this article https://muse.jhu.edu/article/268902 
(and even created, in a way) public debt helped get the new United States to first base.

Wright's is not a novel assessment of either Hamilton's financial program, broadly defined, or his approach to the national debt, but Wright provides fresh details. He argues persuasively that Hamilton used his new sinking fund to blunt the effects of the Panic of 1792 and, in I797, the Baltimore branch of the Bank of the United States, inspired by Hamilton's proactive approach, mitigated the effects of another liquidity crisis. In addition, Wright mobilizes a new sample of federal bondholders to reinforce the view that Hamilton's program resulted in a widely held federal debt that lubricated economic life in the early republic. On this issue, Wright also breaks new ground by offering a biographical survey of federal bondholders who registered their bonds in Virginia. He illustrates how investors of widely diverse sizes and occupations used the bonds to advance a broad range of financial interests. By the I 820 s, Wright proposes, "the public debt served as the bridge between the nation's non-predatory government and its emerging financial system" and "in turn, spurred the crystallization of the rest of American's development diamond, its entrepreneurs, managers, and the business firms they ran" (238).

Wright's ambivalence emerges in his concluding chapter, in which he evaluates the history that unfolded following the completion of President Andrew Jackson's program to extinguish the debt of the early republic. At this juncture, Wright invokes Thomas Jefferson. He was "prescient," Wright says, in considering the national debt as "a monstrous fraud on posterity." Wright suggests that, in the twentieth century (and perhaps even earlier), pandering politicians and self-interested bureaucrats borrowed money excessively to pay for projects less worthy than what the first national debt bought - "the nation's independence and people's liberty" (282). However, Wright's history of the debt since Andrew Jackson's presidency is too cursory to explain either how the nation fell from Hamiltonian grace, or how it might return there in the future. Nonetheless, Wright's innovative history of financing the early republic provides one of the best foundations available for exploring the sources and dynamics of what some scholars now refer to as the "debt state" of the late twentieth and early twenty-first centuries.

W. Elliot Brownlee

University of California, Santa Barbara

Women, Work, and Family in the Antebellum Mountain South. By Wilma Dunaway (New York, Cambridge University Press, 2008) 30I pp. $\$ 80.00$

Dunaway continues her explorations of Appalachia in Women, Work, and Family in the Antebellum Mountain South. In this detailed work, she 
considers how gender, race, and class shaped the lives of the region's most marginal women-slaves, free blacks, poor whites, and natives.

In broad strokes, Dunaway argues that the separate-spheres ideology and "cult of domesticity" promulgated by antebellum writers bore little resemblance to the lives of mountain women. She maintains that poor and enslaved women could not-or would not-maintain the stark dichotomy between home and workplace that was fundamental to the separate-spheres ideology. Whether compelled by force or necessity, women labored in fields, engaged in domestic manufacturing, operated small businesses, and worked as wage laborers. Dunaway carries her argument against separate spheres a step further, concluding that "there was not a clear division between household labors and market commodity production" (I92-I93).

Women's participation in the workforce carried a social price. Poor whites who performed stigmatized labor surrendered their racial prerogatives. As Dunaway notes, "poor white women were often 'racialized' as barbaric throwbacks because their work and family patterns were too similar to those of nonwhite females in the minds of affluent Appalachians" (I27). Those who defied gender and racial norms confronted a legal system that empowered officials to regulate and disrupt the families of poor whites, free blacks, and the enslaved. For those on the bottom of the South's social ladder, the bourgeois family idealized in the "cult of domesticity" proved an elusive dream.

Despite its many strengths, Dunaway's study is not without flaws. Although she is sensitive to chronological change in her discussions of Cherokee women, her treatment of poor whites, free blacks, and slaves is often static. More bothersome is Dunaway's use of secondary sources. On at least two occasions, Dunaway supports assertions about the mountain South with evidence from regions outside Appalachia. ${ }^{1}$ Similar problems plague her use of primary sources. Although Women, Work, and Family rests upon a vast body of research, certain citations are imprecise, and Dunaway's handling of sources is questionable. She notes, for example, that "free born mulatto James Merrick was 'taken in possession' and sold as a slave when his western Maryland employer died"

I For example, Dunaway notes that "Appalachian slaves frequented grog shops, restaurants ... and other small businesses operated by poor whites, and they occasionally purchased the services of white prostitutes" (80). The sole citation offered to support this particular claim is Betty Wood's study of the Georgia lowcountry-Women's Work, Men's Work: The Informal Slave Economies of Lowcountry Georgia (Athens, I995), 7I-79. Although the pages cited discuss the underground economy that developed among slaves and poor whites, the examples are all from Darien, Savannah, and other communities in coastal Georgia. Later in the paragraph, Dunaway cites Midori Takagi's work on antebellum Richmond- "Rearing Wolves to Our Own Destruction": Slavery in Richmond, Virginia, 1782-1865 (Charlottesville, I999)— to support her claim that " $[\mathrm{t}]$ raveling peddlers and hucksters regularly traded goods to slaves, and poor whites often purchased items from slaves." Thus, at least some of Dunaway's claims about the mountain South are backed by studies that have nothing to do with the region. 
(252). In support, Dunaway cites page I 34 of Rose's anthology A Documentary History of Slavery in North America, but this page contains no reference to Merrick or the enslavement of free blacks; it discusses Nat Turner. $^{2}$

Likewise, Dunaway quotes a Virginia slaveholder who worried that "a death struggle must come between the two classes, on which one or the other w[ould] be extinguished forever" (I23). Because the quotation is situated within a paragraph about tensions between planters and landless whites, the implication is that the anonymous master feared an intraracial class conflict. In actuality, the "death struggle" that this slaveholder feared was an interracial conflagration. Dunaway's anonymous slaveholder was Henry Berry of Virginia, who was raising the specter of slave revolts in the aftermath of Nat Turner's I 83 I rebellion. Addressing the Virginia House of Delegates, Berry contended that harsher slave codes offered little protection against insurrections and that Virginia faced a "mighty avalanche" unless it abolished slavery. ${ }^{3}$ Whether these are isolated-even trifling-incidents or symptoms of larger, more systemic problems must remain for future reviewers to decide, but they do raise questions about the precision of Dunaway's research.

Max Grivno University of Southern Mississippi

The Big Tent: The Traveling Circus in Georgia, 1820-1930. By Gregory J. Renoff (Athens, University of Georgia Press, 2008) 235 pp. $\$ 34.95$

In this fine cultural study, Renoff explores the interaction between southern communities and the circus during the heyday of the traveling big top. Those with a general interest in popular culture or a specific interest in circus history will doubtlessly find much to appreciate in Renoff's recounting of the traveling show's theatrical evolution throughout the late nineteenth and early twentieth century. Yet this work delivers much more, constructing an innovative social, cultural, and economic analysis of a broad spectrum of Georgia's diverse population. It accomplishes this feat by paying as much attention to the individuals who made up the communities that hosted the traveling circus as it does to the show itself.

Renoff's work builds around the notion of "circus day" as a kind of secular holiday during which a collective representation of community

2 Willie Lee Rose (ed.), A Documentary History of Slavery in North America (New York, I976), I 34.

3 Dunaway's source for the quotation was John McKivigan (ed.), The Roving Editor or Talks with Slaves in the Southern States (University Park, I996), 99. This reviewer, however, located the quotation in the original edition of the book. James Redpath, The Roving Editor: or, Talks with Slaves in the Southern States (New York, I859), I00-I02. 